\title{
Heteromysis (Heteromysis) microps (Crustacea, Mysidae), a commensal species for Upogebia pusilla (Crustacea, Upogebiidae) in Arcachon Bay (NE Atlantic Ocean)
}

\author{
Nicolas Lavesque ${ }^{1,2^{*}}$, Ludovic Pascal ${ }^{1,2}$, Benoit Gouillieux ${ }^{1,2}$, Jean-Claude Sorbe ${ }^{1,2}$, Guy Bachelet ${ }^{1,2}$ \\ and Olivier Maire ${ }^{1,2}$
}

\begin{abstract}
Background: The mysid Heteromysis (Heteromysis) microps is reported for the first time in the Bay of Biscay. During surveys carried out between March and September 2015 in Arcachon Bay, mysid specimens were fortuitously collected from Upogebia pusilla burrows.

Results: Details on morphology, colour pattern and behaviour of H. microps are provided.

Conclusions: Commensalism was frequently mentioned for Heteromysis species but never reported for $\mathrm{H}$. microps. In this study, commensalism seems to be proved between the mysid and its host U. pusilla.
\end{abstract}

Keywords: Heteromysis (Heteromysis) microps, Upogebia pusilla burrows, Commensalism

\section{Background}

The thalassinidean mud shrimp Upogebia pusilla (Petagna, 1792) occurs in high densities in intertidal flats in the NE Atlantic and in shallow lagoons in the Mediterranean Sea. As its Y-shaped burrows penetrates deep into the sediment (up to $1 \mathrm{~m}$ ), this shrimp is considered an important ecosystem engineer (Jones et al., 1994; Pillay and Branch, 2011). Indeed, through its intense bioturbation activity, it greatly influences sedimentary biogeochemical processes and enhances fluxes across the sediment-water interface with knock-on effects on the whole benthic communities (Ziebis et al., 1996; D'Andrea and DeWitt, 2009; Pascal et al., 2016). Upogebia also intensively ventilate their burrows through pleopod beating (Dworschak, 1981) for respiratory and trophic requirements (Sato et al., 2001). Deep and well irrigated

\footnotetext{
* Correspondence: n.lavesque@epoc.u-bordeaux1.fr
${ }^{1}$ University Bordeaux, EPOC, UMR 5805, Station Marine d'Arcachon, 2 Rue du

* Correspondence: n.lavesque@epoc.u-bordeaux1.fr
${ }^{1}$ University Bordeaux, EPOC, UMR 5805, Station Marine d'Arcachon, 2 Rue du Professeur Jolyet, Arcachon 33120, France

${ }^{2}$ CNRS, EPOC, UMR 5805, Station Marine d'Arcachon, 2 Rue du Professeur Jolyet, Arcachon 33120, France
}

mud-shrimp burrows represent efficient refuges against predation for a variety of commensal species such as shrimps (e.g. Betaeus longidactylus Lockington, 1877) (Campos et al., 2009), pea crabs (e.g. Scleroplax granulata Rathbun, 1894) (Campos, 2006), bivalves (e.g. Peregrinamor ohshimai Shôji, 1938) (Kato and Itani, 1995), polychaetes (e.g. Hesperonoe hwanghaiensis Uschakov \& Wu, 1959) (Sato et al., 2001), phoronids (e.g. Phoronis pallida Silén, 1952) (Santaga, 2004) and goby fishes (e.g. Eutaeilichthys gilli Jordan \& Snyder, 1901) (Henmi and Itani, 2014). During a recent study aiming at quantifying the ince of $U$. pusilla on porewater exchanges and nutri(Pascal et al., 2016), specimens of Heteromysis chisis) microps (G.O. Sars, 1877) were fortuitously collected in their burrows from tidal flats of Arcachon Bay, thus providing the opportunity for new observations on the morphology and behaviour of this rare species in European waters. 


\section{Results}

\section{Systematics}

Family MYSIDAE Haworth, 1825

Subfamily Heteromysinae Norman, 1892

Genus Heteromysis S.I. Smith, 1873

Subgenus Heteromysis (Heteromysis) S.I Smith, 1873

Heteromysis (Heteromysis) microps (G.O. Sars, 1877)

Type species: Heteromysis (Heteromysis) formosa Smith, 1873

\section{Material examined}

For the 68 specimens of $H$. microps collected, size and sex were determined. The sex-ratio of the population was 2:3 (male:female). Brooding females were absent from March samples and represented $44.4 \%$ and $60 \%$ of the total females in July and September, respectively. The size range of individual body length $\mathrm{BL}$ was measured in each demographic category: 5.59-9.27 mm $(7.42 \pm 1.10 \mathrm{~mm}$; $\overline{\mathrm{x}} \pm \mathrm{s})$ in males, $5.27-8.73 \mathrm{~mm}(6.44 \pm 0.84 \mathrm{~mm})$ in females and $6.99-9.44 \mathrm{~mm}(8.07 \pm 0.87 \mathrm{~mm})$ in brooding females. Juveniles were never collected during our survey.

\section{Generic diagnosis (according to Wittmann, 2000)}

Heteromysinae with eyes normal. Appendix masculina representing a very small setose lobe or reduced to a setose ridge. Antennal scale usually short, setose all around, without or with a small apical article. Mouthparts normal; labrum not produced into a spiniform process. First thoracic endopod with a large endite on the basis, and smaller endites on ischium and merus (an additional small, conical endite may be present on the coxa, although rarely noted by previous authors). Third thoracic endopod subchela-like (gnathopod), with enlarged carpopropodus and strong dactylus. Carpopropodus of fourth to eighth thoracic endopods with 3-7 articles. Penis long and more or less cylindrical. Pleopods entire, reduced to small plates in both sexes; nondimorphic (subgenus Heteromysis) or dimorphic (some other subgenera). Uropods normal, entire; exopod with setae all around; endopod without or in most species with stout setae along inner margin. Telson with stout setae on lateral margins; distinct apical cleft present, margins of cleft with a number of laminae.

\section{Description}

Based on two males (Arcachon Marine Station Collection), $\mathrm{BL}=7.52 \mathrm{~mm}$ and $7.89 \mathrm{~mm}$, Arcachon Bay, March 2015.

Antennal scale small, shorter than antennular peduncle. Sternal processes absent in females, present on second to eighth sternites in males: first anterior one with blunt bifid apex, subsequent ones with more or less acute bifid tip and the last posterior one very reduced and coneshaped (Fig. 1a). Endopod of thoracopod 3 (gnathopod)

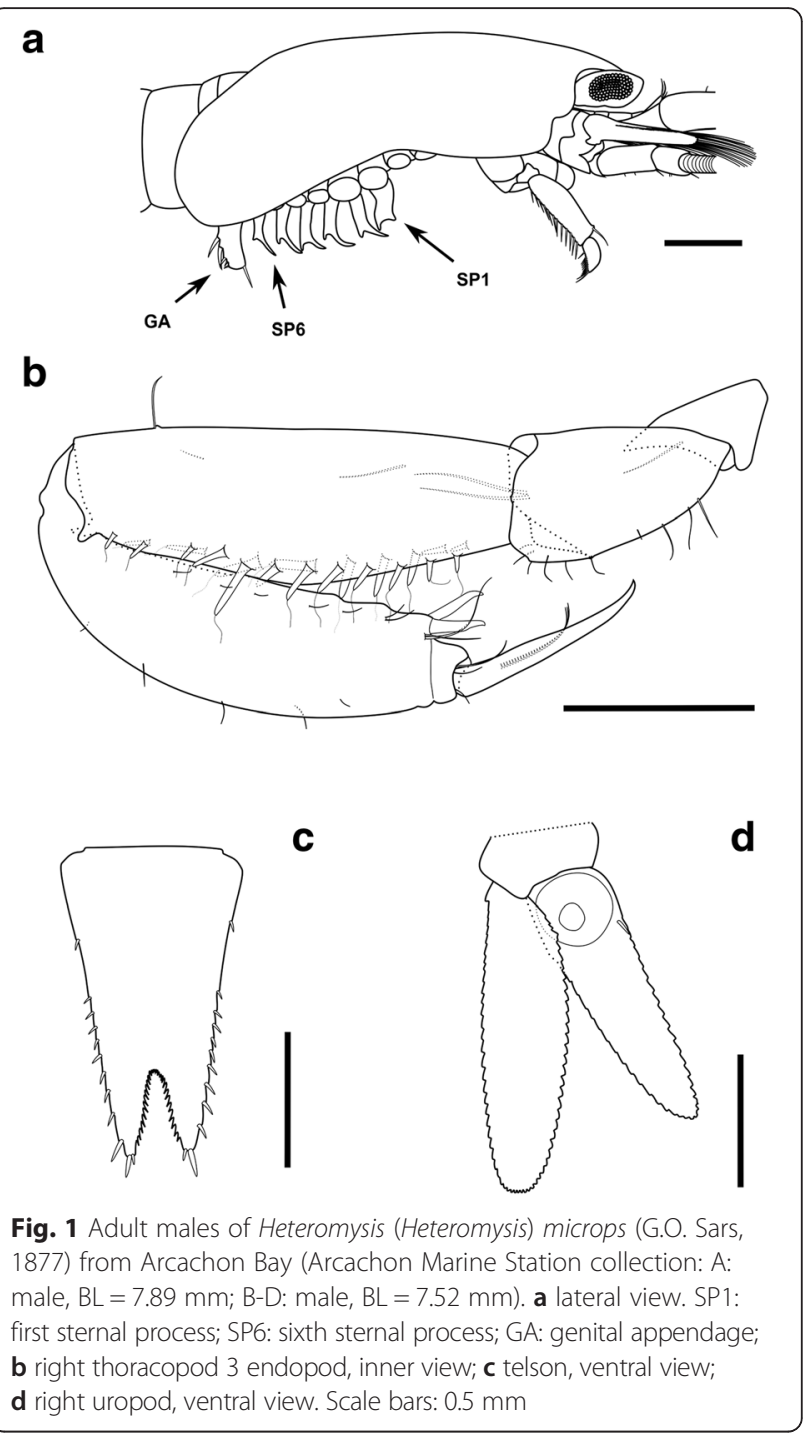

very robust, longer than cephalothorax, non-dimorphic; merus large, bearing 12 cuspidate setae on ventral margin of inner face (from 11 to 16 for other specimens), 9 cuspidate setae on ventral margin of outer face (from 8 to 11 for other specimens), 1 sub-distal seta on dorsal margin (Fig. 1b), ventrodistal part with an inner roundish lobe and an outer acute lobe between which carpopropodus folds down; carpopropodus with one pair of cuspidate setae at ventrodistal angle between which dactylus bends down to form a powerful subchela; dactylus with 3 long, tip-curved setae along outer face (Fig. 1b). Pleopods normal, non-dimorphic. Telson cleft, with 1 stout seta on basal third of lateral margin, followed by a naked portion and then 9 stout setae on distal half ( 7 to 10 stout setae on other specimens) (Fig. 1c). Uropod endopod with 1 stout seta on proximal part of inner margin, near statocyst (Fig. 1d). 


\section{Remarks (based on Sars (1877) and Tattersall and Tattersall (1951))}

Sars (1877) described only adult females and Tattersall and Tattersall (1951) described only a single adult male. All the data on females given by the last authors were depicted from Sars (1877).

\section{Telson:}

Tattersall and Tattersall (1951) re-described H. microps with a telson armed with 12-14 stout setae on each side. The Arcachon specimens show no more than 11 stout setae (one near the base and 10 on the distal half) as first described by Sars (1877) in the original description of H. microps.

\section{Thoracopod 3:}

All the Arcachon specimens bear 3 long setae on their dactylus. Tattersall and Tattersall (1951) mentioned the presence of two subdistal pairs of small stout setae as well as a pair of distal finger-like projections along the ventral margin of the carpopropodus (proximal article). However, in Sars's original description of this species (1877; Fig. 20-9), the subdistal stout setae are clearly more developed and the 'distal finger-like projections' are in fact represented as a pair of articulated stout setae (shorter than the other ones). Our own observations on Arcachon specimens confirm Sars's original interpretation (a pair of distal stout setae, not finger-like projections), but without two pairs of stout setae along the carpopropodus inner margin (rarely with one short pair). Tattersall and Tattersall (1951) mentioned the presence of 10 sensitive stout pedestal setae (probably 12 of these setae in Sars's original description) and one distal setal tuft along the merus inner margin. Such a setal tuft was not observed in Arcachon specimens and 11-16 sensitive stout pedestal setae were counted on their merus inner margin. Furthermore, setal ornamentation shows some slight differences between right and left thoracopod 3 endopods, when considering a single specimen.

\section{Coloration}

As the specimens were observed alive after capture, new data on their colour pattern can be provided. General appearance orange (Fig. 2a). Cornea brown-golden, surrounded by pink-red coloration (Fig. 2b). Eyes and antennae iridescent (Fig. 2b). Cephalon rust-coloured (Fig. 2a). Rust-coloured chromatophores scattered dorsally and laterally over carapace and between $6^{\text {th }}$ abdominal segment and telson. Appendages and uropods not pigmented. Eggs brown. The body coloration disappeared within a few minutes after fixation (alcohol or formalin).
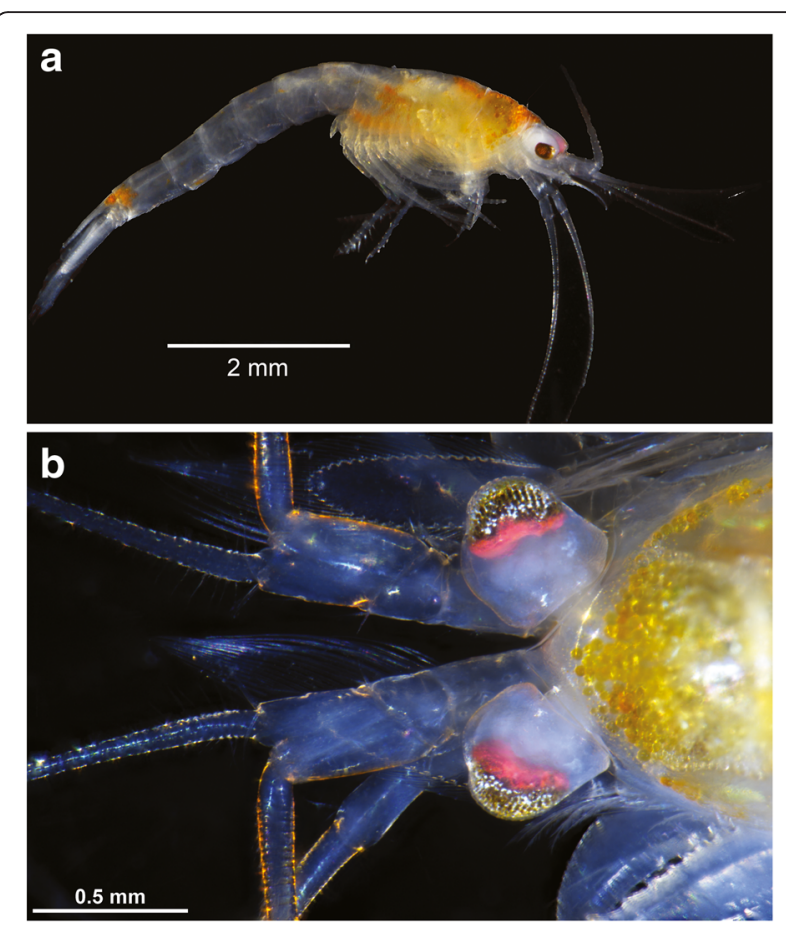

Fig. 2 Living male specimen of Heteromysis (Heteromysis) microps (G.O. Sars, 1877) from Arcachon Bay (BL=7.52 mm) (Arcachon Marine Station collection, same specimen as in Fig. 1b-d). a lateral view; b anterior part

\section{Geographical distribution and habitat}

Relatively rare species, from Norwegian coast to Mediterranean Sea (Tattersall and Tattersall 1951; Tattersall, 1967; Dauvin and Vallet, 1997). In coastal areas, from 6 to $33 \mathrm{~m}$ depth, on mud to pebble bottoms (Zouhiri et al., 1998), Posidonia oceanica (Linnaeus) Delile, 1813 meadows (Wittmann, 2001) and, according to the present study, within burrows of $U$. pusilla in intertidal Zostera noltei meadows.

\section{Discussion}

The genus Heteromysis is divided in 4 subgenera and is the most speciose of the Mysidae with 82 species currently considered valid (Mees, 2015). Only one species was previously mentioned from the southern Bay of Biscay: Heteromysis (Heteromysis) norvegica G.O. Sars, 1882, on bathyal bottoms (Frutos and Sorbe, 2014). Members of this genus are generally distributed in coastal warm-water regions and most of the species are restricted to small geographical areas (Fukuoka, 2005). This study reports on the first record of $H$. microps in the Bay of Biscay, and most importantly, its first record in association with another invertebrate species. Despite an important number of macrobenthic studies since the 1960s in Arcachon Bay (see Blanchet, 2004) and particularly in Z. noltei meadows (Blanchet et al., 2004), $H$. 
microps was never found in that bay. Therefore, this mysid should not be considered as a new inhabitant of Arcachon Bay, and its absence in previous ecological studies can be explained by the lack of specific investigations on Upogebia pusilla burrows before 2015. H. microps is probably commensal with this burrowing shrimp. As it usually occurs on soft bottoms (Zouhiri et al., 1998) and in seagrass meadows (Wittmann, 2001), the association found in this study could be a local phenomenon.

Coastal mysids, and particularly species belonging to the genus Heteromysis, are known to prefer complex habitats such as dense vegetation, shells and gravels or to live in association with different invertebrate species (Wittmann, 2008). Commensalism in the genus Heteromysis was first demonstrated by Clarke (1955), describing an association between Heteromysis actiniae Clarke, 1955 and the sea-anemone Bartholomea annulata (Lesueur, 1817) in Bahamas Islands (Tattersall, 1967). Heteromysis species are known to have various hosts like sponges, corals, gorgonians, sea anemones, brittle stars and hermit crabs inhabiting empty shells (Wittmann, 2008; Wittmann et al., 2014). In Arcachon Bay, Upogebia burrows provide peculiar microhabitats where mysids can live more safely against predation and environmental perturbations as well as against desiccation at low tide.

According to Dworschak (1987), $U$. pusilla is primarily a filter-feeding species, generating a water flow into its burrow by pleopods beating. Astall et al. (1997) demonstrated that the mean irrigation rate into the burrows of Upogebia deltaura (Leach, 1815) and U. stellata (Montagu, 1808) were $149.5 \mathrm{ml} . \mathrm{h}^{-1}$ and $139.7 \mathrm{ml} . \mathrm{h}^{-1}$, respectively. The suspended material associated with water flow is driven to the "basket" formed by the long setae beared by pereopods 1-2, then transferred to the mouthparts by maxilliped 3 (Dworschak, 2004). As H. microps is a suspension feeder (Mees, 2016), this species could take advantage of the particle flow generated by the Upogebia host within its burrow. This nutritional model has been previously reported by Vannini et al. (1994) for Heteromysis (Gnathomysis) harpax (Hilgendorf, 1878). This latter species is associated with hermit crabs belonging to the genus Dardanus Paul'son, 1875 and ingests suspended particles brought into the gill chamber by the host. According to Dworschak (1987), U. pusilla is also a deposit feeder via a 'gardening' behaviour. Indeed, this decapod can actively store detritus and plant fragments in the walls of its burrow, consuming them with their associated microflora. Mysids are also able to pick up detritus particles with their anterior thoracopods (Albertson, 2004). Unexpectedly, the huge thoracopod 3 of $H$. microps (a morphological peculiarity of this genus) does not appear to be related to a predator behaviour but could be used to consume the organic particles stored in Upogebia burrows. Furthermore, San Vicente and Monniot (2014) suggested that the enlarged thoracopod endopods of Heteromysinae could be used as weapons. With the adoption of a symbiotic life in these taxa, it is suggested that these weaponries probably have played an important role in determining the behaviour and morphological evolution of such mysids (Vannini et al. 1994).

\section{Conclusions}

In this study, commensalism seems to be proved between the mysid and its host. As the mysid associate remains external and was never found in another habitat in Arcachon Bay, the association between $H$. microps and $U$. pusilla may be classified as obligatory ectocommensalism (Nardon and Charles, 2002; San Vicente and Monniot, 2014). H. microps seems to take advantage of the filter feeding and the gardening behaviour of $U$. pusilla. Furthermore, $H$. microps is clearly protected from predators within $U$. pusilla burrows.

Further studies will be conducted to understand the behaviour of both species (laboratory experiments in thin aquariums, each colonized by one $U$. pusilla specimen). These mesocosm observations will allow answering different questions: (1) what is the behaviour of mysids during night time? Indeed, Heteromysis species become actively pelagic at night while they live sheltered during daytime (Tattersall, 1967; Wittmann, 2008); (2) are mysids able to breed within Upogebia burrows, thereby benefiting from some protection for their offspring?; (3) are mysids expulsed from burrows during the breeding period of $U$. pusilla?

\section{Methods}

\section{Study area}

Arcachon Bay is a $180-\mathrm{km}^{2}$ macrotidal coastal lagoon (maximum tidal range: $4.9 \mathrm{~m}$ ) located on the southwestern coast of France (Fig. 3). This lagoon is connected with the Atlantic Ocean by a narrow channel and receives freshwater inputs in its south-eastern part (Leyre River). It is characterized by large intertidal flats $\left(115 \mathrm{~km}^{2}\right)$, the lower parts of which are used for cupped oyster [Crassostrea gigas (Thunberg, 1793)] farming. Most of the intertidal area $\left(46.2 \mathrm{~km}^{2}\right)$ is covered by seagrass beds, Zostera noltei Hornemann, 1832 (Plus et al., 2010). In the inner lagoon, tidal channels represent an area of $71 \mathrm{~km}^{2}$, with $1.02 \mathrm{~km}^{2}$ occupied by eelgrass beds, Zostera marina Linnaeus, 1753 (Plus et al., 2010).

\section{Material examined}

During surveys carried out between March and September 2015, 68 mysid specimens were fortuitously collected from Upogebia pusilla burrows (0-1 individual per burrow), using a bait piston pump and later on identified as $H$. microps according to the identification key published by Wittmann (2008) for Atlantico-Mediterranean 


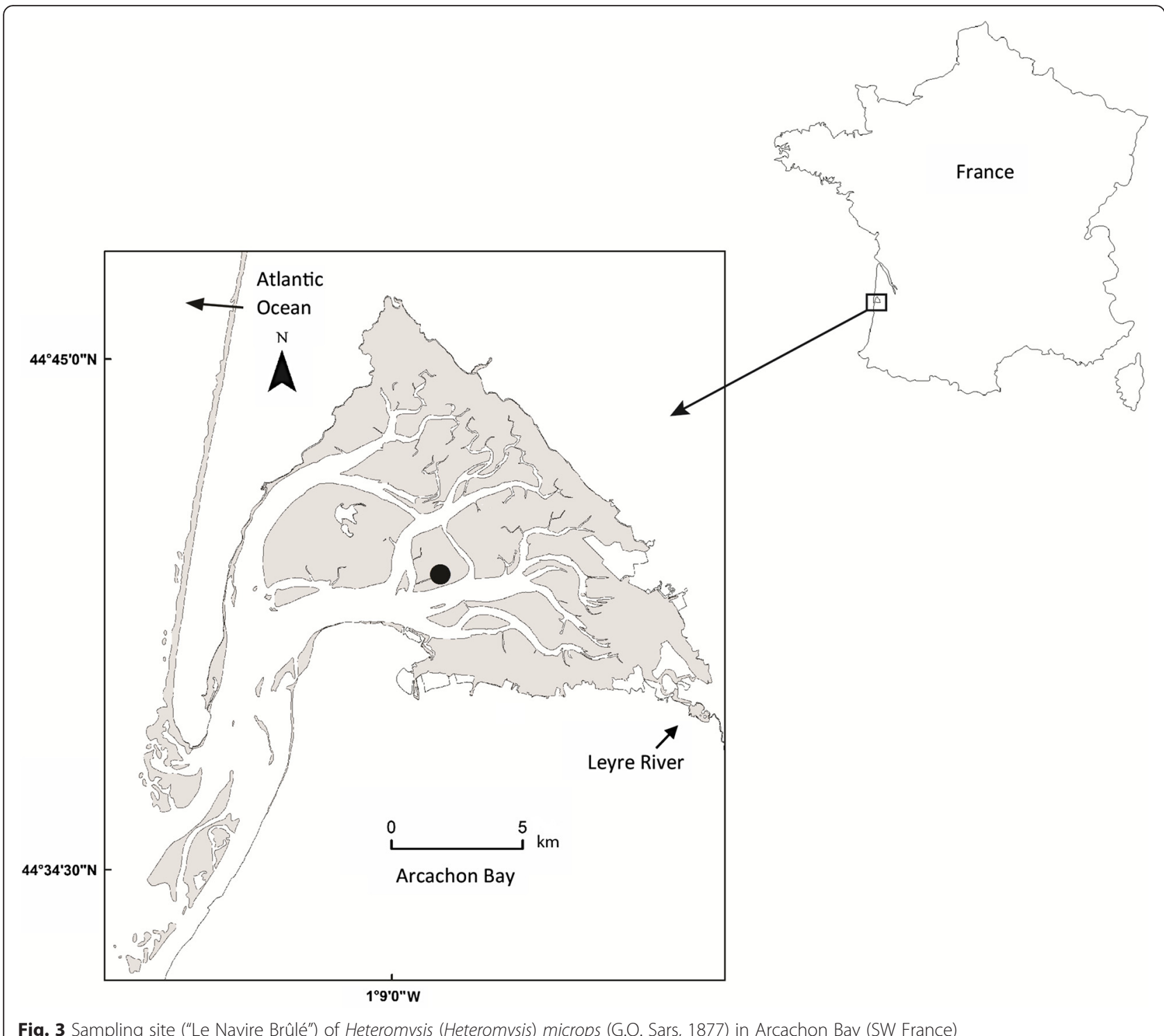

species. Sampling was carried out at low tide within a homogeneous patch of $Z$. noltei at "Navire Brûlé" site (temperature from 7 to $21{ }^{\circ} \mathrm{C}$, salinity from 21.9 to 32.8 ) (Fig. 3). All specimens were examined under a Nikon SMZ25 stereomicroscope and photographed with a Nikon DS-Ri 2 camera, after anaesthetizing them with magnesium chloride $\left(\mathrm{MgCl}_{2}\right)$. An image of one specimen was drawn with a Wacom Intuos 5 tablet, using Inkscape software (v.0.48). Body length BL was measured with the NISElements Analysis software from the rostrum anterior margin to the telson apex.

\section{Availability of supporting data}

Five specimens from Arcachon Bay were deposited in the Muséum National d'Histoire Naturelle, Paris (MNHN-IU2014-10181).
Competing interests

The authors declare that they have no competing interests.

\section{Authors' contributions}

$O M$ and LP discovered for the first time H. microps in U. pusilla burrows. $\mathrm{NL}, \mathrm{BG}$ and JCS identified and described $H$. microps specimens. OM is responsible of the project and LP supervisor. NL wrote the manuscript and $B G, J C S, O M, L P, G B$ significantly improved the final manuscript. All authors read and approved the final manuscript.

\section{Acknowledgments}

Authors thank F. Prince and P. Dusoewoir, captain and crew member of RN Planula IV for help during field work. They also thank three anonymous reviewers for helpful comments on the manuscript. This work is part of Ludovic Pascal's doctoral thesis (University of Bordeaux) financed by a PhD fellowship from the French "Ministère de l'Enseignement Supérieur et de la Recherche". This study has been carried out in the framework of the Cluster of Excellence COTE and was financially supported by the UPO (EC2CO-DRIL) project. 
Received: 27 January 2016 Accepted: 8 February 2016 Published online: 08 March 2016

\section{References}

Albertson J. Trophic interactions involving mysid shrimps (Mysidacea) in the near-bottom habitat in the Baltic Sea. Aquat Ecol. 2004;38:457-69. doi:10.1023/B:AECO.0000035163.30037.38.

Astall CM, Taylor AC, Atkinson JA. Behavioural and physiological implications of a burrow-dwelling lifestyle for two species of upogebiid mud-shrimp (Crustacea: Thalassinidea). Estuar Coast Mar Sci. 1997;44:155-68. doi:10.1006/ecss.1996.0207.

Blanchet $\mathrm{H}$. Structure et fonctionnement des peuplements benthiques du bassin d'Arcachon. Bordeaux: University of Bordeaux; 2004.

Blanchet $\mathrm{H}$, de Montaudouin X, Lucas A, Chardy P. Heterogeneity of macrozoobenthic assemblages within a Zostera noltii seagrass bed: diversity, abundance, biomass and structuring factors. Estuar Coast Mar Sci. 2004;61:111-23. doi:10.1016/j.ecss.2004.04.008.

Campos E. Systematics of the genus Scleroplax Rathbun, 1893 (Crustacea: Brachyura: Pinnotheridae). Zootaxa. 2006;1344:33-41.

Campos E, De Campos AR, Manriquez I. Intertidal thalassinidean shrimps (Thalassinidea, Callianassidae and Upogebiidae) of the west coast of Baja California, Mexico: Annotated checklist, key for identification, and symbionts. Crustaceana. 2009;82:1249-63. doi:10.1163/001121609X12481627024454

Clarke WD. A new species of the genus Heteromysis (Crustacea, Mysidacea) from the Bahama Islands, commensal with a sea-anemone. Am Mus Novit. 1955:1716:1-13.

D'Andrea AF, DeWitt TH. Geochemical ecosystem engineering by the mud shrimp Upogebia pugettensis (Crustacea: Thalassinidae) in Yaquina Bay, Oregon: Densitydependent effects on organic matter remineralization and nutrient cycling. Limnol Oceanogr. 2009:54:1911-32. doi:10.4319//o.2009.54.6.1911.

Dauvin JC, Vallet C. Apports d'échantillonnages suprabenthiques à la faunistique de la Manche et à la biogéographie du plateau continental nord-ouest européen. Crustacés et Pycnogonides. Cah Biol Mar. 1997;38:251-66.

Dworschak PC. The pumping rates of the burrowing shrimp Upogebia pusilla (Petagna) (Decapoda: Thalassinidea). J Exp Mar Biol Ecol. 1981;52:25-35.

Dworschak PC. Feeding behavior of Upogebia pusilla and Callianassa tyrrhena (Crustacea, Decapoda, Thalassinidea). Invest Pesq. 1987:51:421-29.

Dworschak PC. Biology of Mediterranean and Caribbean Thalassinidea (Decapoda). In: Tamaki A, editor. Proceedings of the Symposium "Ecology of large bioturbators in tidal flats and shallow sublittoral sediments - from individuals behavior to their role as ecosystem engineers". Nagasaki: Nagasaki University; 2004. p. 15-22.

Frutos I, Sorbe JC. Bathyal suprabenthic assemblages from the southern margin of the Capbreton Canyon ("Kostarrenkala" area), SE Bay of Biscay. Deep Sea Res II. 2014;102:291-309. doi:10.1016/j.dsr2.2013.09.010.

Fukuoka K. A new species of Heteromysis (Mysida, Mysidae) associated with sponges, from the Uraga Channel, Central Japan, with notes on distribution and habitats within the genus Heteromysis. Crustaceana. 2005;77:1353-73. doi:10.1163/1568540043165976.

Henmi Y, Itani G. Burrow utilization in the goby Eutaeniichthys gilli associated with the mud shrimp Upogebia yokoyai. Zool Sci. 2014;31:523-28.

Jones CG, Lawton JH, Shachak M. Organisms as ecosystem engineers. Oikos. 1994;69:373-86.

Kato M, Itani G. Commensalism of a bivalve, Peregrinamor ohshimai, with a thalassinidean burrowing shrimp, Upogebia major. J Mar Biol Assoc UK 1995:75:941-47. doi:10.1017/S0025315400038261.

Mees J. Heteromysis. In: Mees, J. and Meland K. (Eds) (2012 onwards) World List of Lophogastrida, Stygiomysida and Mysida. World Register of Marine Species. 2015. http://marinespecies.org/aphia.php? $p=$ taxdetails\&id=119863. Accessed $27 \mathrm{Jul} 2015$.

Mees J. Heteromysis (Heteromysis) microps. In: Mees, J. and Meland K. (Eds) (2012 onwards) World List of Lophogastrida, Stygiomysida and Mysida. World Register of Marine Species. 2016. http://marinespecies.org/aphia.php?p= taxdetails\&id=120037. Accessed 3 Jan 2016

Nardon P, Charles H. Morphological aspects of symbiosis. In: Seckbach J, editor. Symbiosis: Mechanisms and Systems. Dordrecht: Kluwer Academic Publishers; 2002. p. 15-44.

Pascal L, Maire O, Volkenborn N, Lecroart P, Bichon S, de Montaudouin X, Grémare A, Deflandre B. Influence of the mud shrimp Upogebia pusilla (Decapoda: Gebiidea) on solute and porewater exchanges in an intertidal seagrass (Zostera noltei) meadow of Arcachon Bay: An experimental assessment. J Exp Mar Biol Ecol. 2016:477:69-79. doi:10.1016/j.jembe.2016.01.008.

Pillay D, Branch GM. Bioengineering effects of burrowing thalassinidean shrimps on marine soft-bottom ecosystems. Oceano Mar Biol. 2011:49:137-92.

Plus M, Dalloyau S, Trut G, Auby I, de Montaudouin X, Emery E, Noel C, Viala C. Longterm evolution (1988-2008) of Zostera spp. meadows in Arcachon Bay (Bay of Biscay). Estuar Coast Shelf Sci. 2010;87:357-66. doi:10.1016/j.ecss.2010.01.016.

San Vicente C, Monniot F. The ascidian-associated mysid Corellamysis eltanina gen.nov., sp.nov. (Mysida, Mysidae, Heteromysinae): a new symbiotic relationship from the Southern Ocean. Zootaxa. 2014;3780:323-46. http://dx.doi.org/10.11646/zootaxa.3780.2.6.

Santaga A. Waterborne behavioral cue for the actinotroch larva of Phoronis pallida (Phoronida) produced by Upogebia pugettensis (Decapoda: Thalassinidea). Biol Bull. 2004;207:103-15.

Sars GO. Nye bidrag til Kundskaben om Middelhavets Invertebratfauna: I. Middelhavets Mysider. Arch Math Naturvid. 1877;2:10-119. Tabs 1-36.

Sato M, Uchida H, Itani G, Yamashita H. Taxonomy and life history of the scale worm Hesperonoe hwanghaiensis (Polychaeta: Polynoidae), newly recorded in Japan, with special reference to commensalism to a burrowing shrimp, Upogebia major. Zool Sci. 2001;18:981-91. doi:10.2108/zsj.18.981.

Tattersall OS. A survey of the genus Heteromysis (Crustacea: Mysidacea) with descriptions of five new species from tropical coastal waters of the Pacific and Indian Oceans, with a key for the identification of the known species of the genus. Trans Zool Soc London. 1967:31:157-93.

Tattersall WM, Tattersall OS. The British Mysidacea. London: The Ray Society; 1951. Vannini M, Ruwa RK, Innocenti G. Notes on the behavior of Heteromysis harpax, a commensal mysid living in hermit crab shells. Ethol Ecol Evol. 1994;3:137-42.

Wittmann KJ. Heteromysis arianii sp. n., a new benthic mysid (Crustacea, Mysidacea) from coralloid habitats in the Gulf of Naples (Mediterranean Sea). Ann Nat Hist Mus Wien. 2000;102:279-90.

Wittmann KJ. Centennial changes in the near-shore mysid fauna of the Gulf of Naples (Mediterranean Sea), with description of Heteromysis riedli sp. n. (Crustacea, Mysidacea). Mar Ecol. 2001;22:85-109.

Wittmann KJ. Two new species of Heteromysini (Mysida: Mysidae) from the island of Madeira (N.E. Atlantic), with notes on sea anemone and hermit crab commensalisms in the genus Heteromysis S.I. Smith, 1873. Crustaceana. 2008; 81:351-74. doi:10.1163/156854008783564037.

Wittmann KJ, Ariani AP, Lagardère JP. Chapter 54. Orders Lophogastrida Boas, 1883, Stygiomysida Tchindonova, 1981, and Mysida Boas, 1883 (also known collectively as Mysidacea). In: Vaupel Klein JC, von Charmantier-Daures M, Schram FR, editors. Treatise on Zoology - Anatomy, Taxonomy, Biology. The Crustacea. Revised and updated, as well as extended from the Traité de Zoologie [founded by P.-P. Grassé], Volume 4 Part B. Leiden: Brill; 2014. p. 189-396.

Ziebis W, Forster S, Huettel M, Jørgensen BB. Complex burrows of the mud shrimp Callianassa truncata and their geochemical impact in the sea bed. Nature. 1996;382:619-22.

Zouhiri S, Vallet C, Mouny P, Dauvin JC. Spatial distribution and biological rhythms of suprabenthic mysids from the English Channel. J Mar Biol Assoc UK. 1998:78:1181-202.

\section{Submit your next manuscript to BioMed Central and we will help you at every step:}

- We accept pre-submission inquiries

- Our selector tool helps you to find the most relevant journal

- We provide round the clock customer support

- Convenient online submission

- Thorough peer review

- Inclusion in PubMed and all major indexing services

- Maximum visibility for your research

Submit your manuscript at www.biomedcentral.com/submit 